International Journal of Engineering, Science and Technology

Vol. 13, No. 1, 2021, pp. 81-87
INTERNATIONAL

JOURNAL OF

ENGINEERING,

SCIENCE AND

TECHNOLOGY

www.ijest1-ng.com

www.ajol.info/index.php/ijest

(C) 2021 MultiCraft Limited. All rights reserved

\title{
Adsorptive removal of methylene blue dye from soapnut shell \& pineapple waste derived activated carbon
}

\author{
Ratnesh Kumar Patel $^{1,2 *}$, Ram Prasad ${ }^{2}$, Ravi Shankar ${ }^{1}$, Prateek Khare ${ }^{1}$, Maharshi Yadav ${ }^{1}$

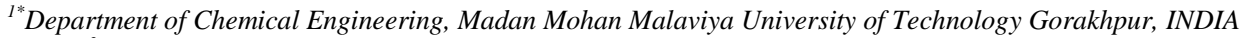 \\ ${ }^{2}$ Department of Chemical Engineering, Harcourt Butler Technological Institute Kanpur, INDIA \\ "Corresponding Author: e-mail: ratnesh.patel1991@gmail.com, Tel +91-7895901264
}

\begin{abstract}
The methylene blue (MB) adsorption from the aqueous solution on activated charcoal from soapnut shell \& pineapple waste were studied in batch mode. The influence of a major parameter determining the efficiency of the process, such as the initial concentration, the adsorbent dose and the contact time on the removal process, was studied. Experimental studies have shown that the adsorption capacity of methylene blue increases with the increase of the adsorbent dose and decreases with the increase of the initial concentration. The equilibrium time of $120 \mathrm{~min}$ was observed. The considered optimal dose for removing methylene blue from aqueous solutions from soapnut shell \& pineapple waste were $0.6 \mathrm{~g} \& 1 \mathrm{~g}$ respectively. The equilibrium data corresponds precisely to the Langmuir isotherm.
\end{abstract}

Keywords: adsorption, methylene blue, soapnut shell, pineapple waste, langmuir isotherm

DOI: http://dx.doi.org/10.4314/ijest.v13i1.12S

Cite this article as:

Patel R.K., Prasad R., Shankar R., Khare P., Yadav M. 2021. Adsorptive removal of methylene blue dye from soapnut shell \& pineapple waste derived activated carbon. International Journal of Engineering, Science and Technology, Vol. 13, No. 1, pp. 81-87. doi: 10.4314/ijest.v13i1.12S

Received: December 1, 2019; Accepted: February 5, 2021; Final acceptance in revised form: March 31, 2021

This paper was earlier presented at the International Conference on Energy, Environment \& Material Sciences (ICE2M), 1-3 December 2019 and substantially improved for this Special Issue. Guest Editor: Dr. Sri Niwas Singh, Professor (HAG), Department of Electrical Engineering, Indian Institute of Technology Kanpur, 208016 (U.P.) India, former Vice-Chancellor, Madan Mohan Malviya University of Technology Gorakhpur (April 2017 to July 2020).

\section{Introduction}

Polluting effluents by various chemical industries like the textile, color dye, cosmetic \& beauty product, paper and pulp and food processing industries contains significant amount of coloring agent and these harmful coloring agents transported to surface water streams that can cause various environmental and ecological problems (Singh, Mohan, Sinha, Tondon, \& Gosh, 2003). "Water is life" but over the time water is also become source of various problems because of anthropogenic activities. Day by day more and more pollutant increasing in water resources, pollution condition become worsen when it comes to developing countries.

Dye is one of toxic pollutant and it needs to remove from wastewater before it discharges in water resources (Öden \& R, 2014). Dyes cause carcinogenic effects on human body due to their toxicity. Ecological system of aquatic biota is highly sensitive to sunlight reaching up to plants inside the aquatic body and we know even very low amount of dyes can cause huge difference in strength of light passing through it. For example, less than $1 \mathrm{ppm}$ concentration of methylene blue dye can reduce light up to that limit where photosynthesis can be prohibited, so this is very important to remove dyes from wastewater before it discharges to water bodies (Patil, Renukdas, \& Patel, 2011; Singh et al., 2003). Many methods and advanced technologies are developed in last few decades for wastewater treatment such as chemical precipitation, various filtration technology, technologies based on ion 
exchanges, reverse osmosis and many more but these technologies have own limitations for dyes removal and cost effectiveness. Due to high efficiency and easy recovery adsorption is remain as most favorable for the pollutant removal (Patel \& Vashi, 2012). Removal of dyes using activated charcoal highly used in research activities. Biomass wastes such as corncobs, coconut shells, palm skins, apple pulp, chickpea peel, olive and walnut shells, cherry stones, rice bran, oil palm peels, tea wastes, bagasse of sugarcane and waste of palm oil fruit bundles have been found to be appropriate for making activated carbon. It is reported by various researchers that high surface area of activated carbon, high yields and better porous structure is achieved in chemical activation comparing to the physical activation (Sunanda, Tiwari, Sharma, \& Raunija, 2013).

In this research activity soapnut shell and pineapple waste being used for making activated carbon, soapnut shell contains high carbon and low inorganic substances which is suitable for chemical activation (Ozer, Imamoglu, Turhan, \& Boysan, 2012). Using soapnut shells and pineapple waste together for producing activated carbon is reported very limited in literature.

Among the many reagents proposed for chemical activation zinc chloride $\left(\mathrm{ZnCl}_{2}\right)$, phosphoric acid $\left(\mathrm{H}_{3} \mathrm{PO}_{4}\right)$, aluminum chloride, magnesium chloride, potassium hydroxide $(\mathrm{KOH})$, sodium hydroxide $(\mathrm{NaOH})$ etc. out of which $\mathrm{ZnCl}_{2}, \mathrm{H}_{3} \mathrm{PO}_{4}$, and $\mathrm{KOH}_{\text {, }}$ are the most commonly used (Gong, Xie, Yang, \& Yao, 2013; Kumar, Ramalingam, \& Sathish kumar, 2011; Pathania, Sharma, \& Singh, 2017).

This research aims to investigate and analyze adsorption efficiency of activated carbon prepared by using soapnut shells and pineapple waste for removal of methylene blue dyes from aqueous solution.

\section{Material and Methods}

2.1 Material: Soapnut seeds and pineapple waste are purchased from local shop in Kanpur. Synthetic wastewater was prepared from methylene blue dye $\mathrm{C}_{16} \mathrm{H}_{18} \mathrm{CIN}_{3} \mathrm{~S}$ (Molar mass: $319.85 \mathrm{~g} / \mathrm{mol}$ ). High grade chemicals were used for experiment such as hydrochloric acid, sodium hydroxide, ortho phosphoric acid, sodium thiosulphate, iodine solution, sulphuric acid, starch, purchased from Thomas Baker.

2.2 Feed preparation: The seeds are broken manually in a traditional iron mortar-pestle. The internal flexible part from the soapnut is discarded because its adsorption capacity may be low and hard shell of the seed used for preparation of activated carbon. After washing the shell and pineapple waste with double-distilled water and at $105{ }^{\circ} \mathrm{C}$ it is dried in a laboratory hot air oven for $24 \mathrm{hrs}$. The shells of dried soapnut shell and pineapple waste were grinded in smaller size.

2.3 Activated carbon preparation: The coarse soapnut shell and pineapple waste are mixed with phosphoric acid $\left(\mathrm{H}_{3} \mathrm{PO}_{4}\right)$ in the $1: 1 \mathrm{w} / \mathrm{v}$ ratio and kept for digestion in hot air oven at $100{ }^{\circ} \mathrm{C}$ for 3 hours. Now this mixture is kept in muffle furnace at $500{ }^{\circ} \mathrm{C}$ for 1 hour 30 minutes. After carbonization the treated material is removed from the muffle furnace and place in desiccator for cool down to the room temperature. The material is washed several times with double-distilled water to eradicate the hints of free acid until it attains the $\mathrm{pH}$ value of 6 . After that activated carbon is dried in laboratory hot air oven for 5 hours at $105{ }^{\circ} \mathrm{C}$. The produced activated carbon is crushed, sieved and stored in moisture proof container.

\section{Results and Discussion}

3.1 Proximate analysis: The proximate analysis of the samples is done with standard method and yielded the following results shown in Table 1:

Table 1. Proximate analysis

\begin{tabular}{|c|c|c|c|}
\hline \multirow{2}{*}{ S.N. } & \multirow{2}{*}{ Content } & \multicolumn{2}{|c|}{ Amount , \% } \\
\cline { 3 - 4 } & & Soapnut Shell & Pineapple Waste \\
\hline $\mathbf{1}$ & Moisture & 5.08 & 2.31 \\
\hline $\mathbf{2}$ & Ash & 11.37 & 4.48 \\
\hline $\mathbf{3}$ & Volatile Matter & 58.43 & 77.35 \\
\hline $\mathbf{4}$ & Fixed Carbon & 25.12 & 15.56 \\
\hline
\end{tabular}

Proximate analysis aids us to evaluate the amount of moisture, volatile, ash content and residual carbon present in the sample (Kurniawan \& Ismadji, 2011). Result shows that the amount of moisture in soapnut shell is significantly high while ash and volatile content are low. The fixed carbon content in soapnut shell is high as comparison to pineapple waste.

3.2 Yield and characterization of activated carbon: The various characterization data is shown in Table 2 such as BET, pH, bulk density, yield of activated carbon etc. There is significant changes in data for both precursor i.e. soapnut shell and pineapple waste. 
Table 2. Different properties of activated carbon

\begin{tabular}{|l|l|l|l|}
\hline S.N. & Properties & Soapnut Shell & Pineapple Waste \\
\hline 1 & Activated Carbon Yield, $\%$ & 40.97 & 35.48 \\
\hline 2 & Bulk density, g/mL & 0.383 & 0.417 \\
\hline 3 & Iodine number, $\mathrm{mg} / \mathrm{g}$ & 1248.93 & 785.85 \\
\hline 4 & $\mathrm{pH}$ & 6.76 & 6.28 \\
\hline 5 & BET surface area, $\mathrm{m}^{2} / \mathrm{g}$ & 1287.770 & 987.890 \\
\hline 6 & Average pore radius , $\AA$ & $1.39 \times 10^{1}$ & $1.31 \times 10^{1}$ \\
\hline 7 & Total pore volume, cc/g & $8.9 \times 10^{-1}$ & $8.3 \times 10^{-1}$ \\
\hline
\end{tabular}

3.3 SEM analysis: The scanning electron microscopy (SEM) analysis was used to observe surface morphology of activated carbon. Figure 1 clearly shows that widespread variety of pores and fibrous structure are present in activated carbon.
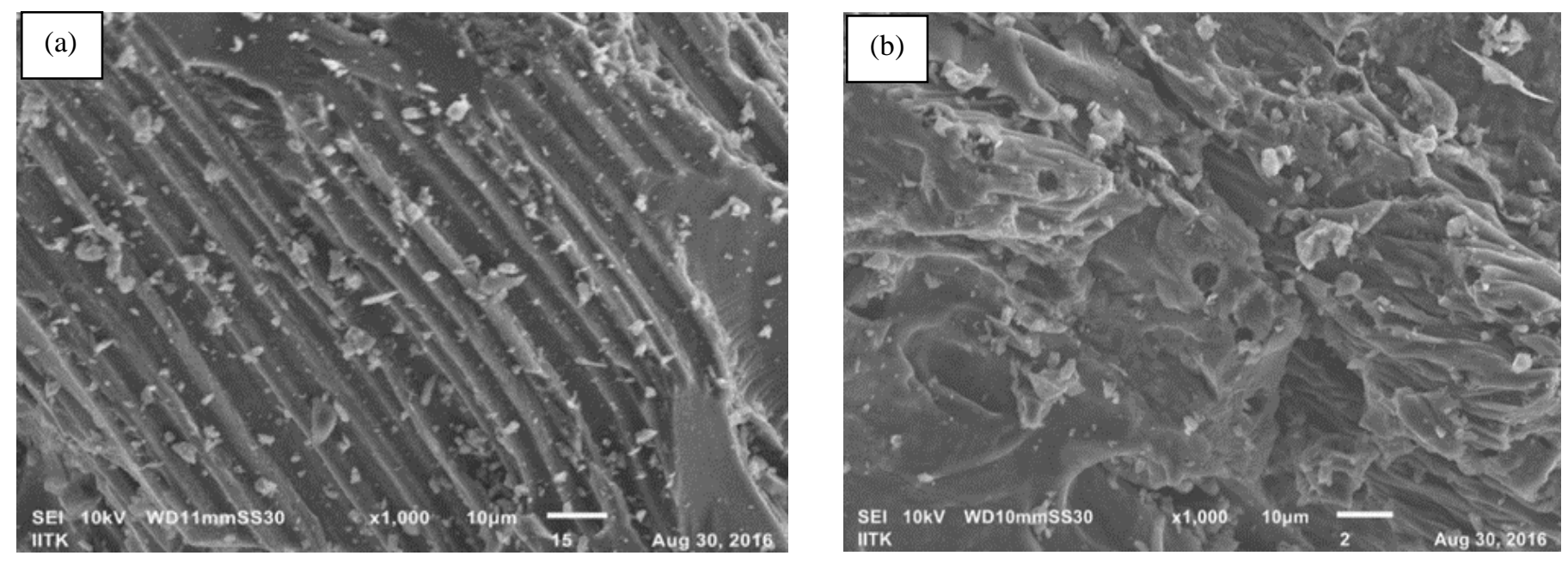

Figure 1. SEM Images of (a) Soapnut shell (b) Pineapple waste

3.4 Calibration curve: To obtain the amount, adsorption of methylene blue dye by activated carbon, an absorbance calibration curve versus concentration was drawn. Methylene blue dye was prepared at different concentrations and its absorbance was measured by spectrophotometer. The graphical representation of absorbance versus concentration provided a straight line through the origin as shown in Figure 2. This was used in conjunction with the various absorbance values of $668 \mathrm{~nm}$ wavelength light samples.

$$
y=0.0939 x+0.0065
$$

By equation 1 we can find the equilibrium concentration of the sample. The percentage color removal is given by Equation (2):

$$
\% \text { color removal }=\frac{C_{0}-C_{e}}{C_{0}} \times 100
$$

where $\mathrm{C}_{0}(\mathrm{mg} / \mathrm{L})$ and $\mathrm{C}_{\mathrm{e}}(\mathrm{mg} / \mathrm{L})$ is the initial and equilibrium concentration of the sample. 


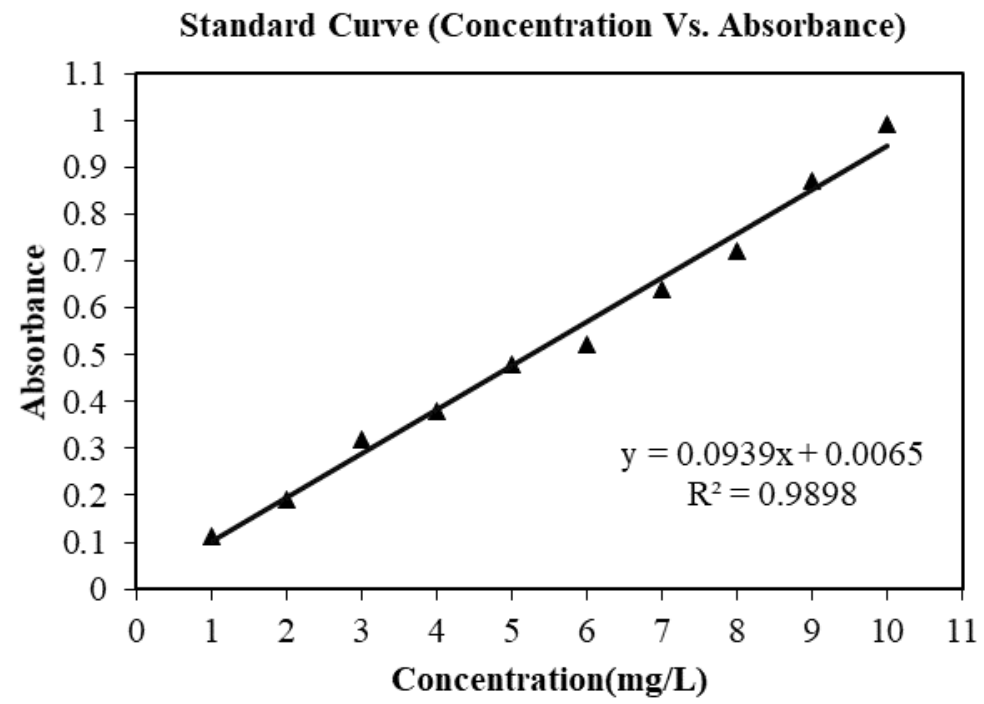

Figure 2. Calibration curve

3.5 Effect of initial concentration on adsorption: Adsorption experiments were carried out in the concentration range (10-50 mg/L) and an adsorbent dose of $0.5 \mathrm{~g}$. The amount of adsorbed MB decreases with increasing initial concentration, while maximum adsorption is obtained at the lowest concentration. The initial concentration of MB was plotted against the adsorption percentage of MB (Figure 3). The observed trend shows that it is higher in soapnut shell in comparison to pineapple waste. The amount of dye adsorbed per unit mass by adsorbent highly dependent on initial concentration of dye, at lower concentration it possesses maximum removal of MB (Mahapatra, Ramteke, \& Paliwal, 2012; Yang \& Qiu, 2010).

\section{Effect of Initial Concentration on Adsorption}

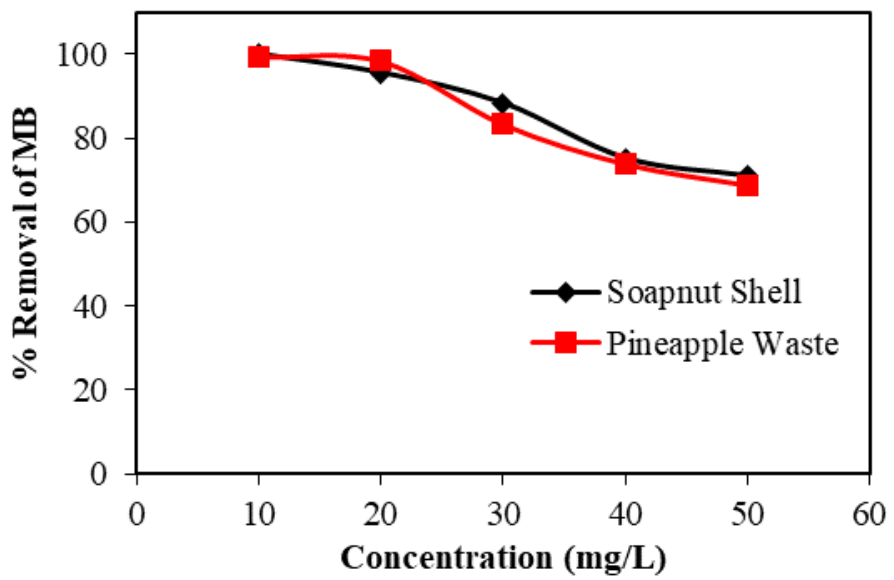

Figure 3. \% Removal of MB vs Initial concentration by Soapnut shell and Pineapple waste (Amount of adsorbent $=0.5 \mathrm{~g}$, Adsorption time $=2 \mathrm{hr}$, Volume of adsorbate $=100 \mathrm{ml}$ )

3.6 Effect of adsorbent dose on adsorption: Effect of various amount of adsorbent is studied at constant time to investigate minimum amount of adsorbent required to achieve $\sim 100 \%$ adsorption, $0.2,0.4,0.6,0.8,1.0 \mathrm{~g}$ of absorbent is used respectively, concentration of MB dyes is taken 100ppm (sample volume $100 \mathrm{ml}$ ). As expected, increase of absorbent amount increases the adsorption of MB dye, $0.6 \mathrm{~g}$ of soapnut activated carbon is achieved nearly $100 \%$ adsorption and for same amount of adsorption $1 \mathrm{~g}$ of pineapple waste activated carbon utilized. Above analysis concluded that $1 \mathrm{~g}$ and $0.6 \mathrm{~g}$ are respectively amount of pineapple waste activated carbon and soapnut activated carbon for removing 100ppm MB dyes solution of $100 \mathrm{ml}$. for economical point of view soapnut activated carbon finds to be more feasible for dye removal (Dargo, Gabbiye, \& Ayalew, 2015; Mohammed MA, Shitu A, \& Ibrahim A, 2014). 
Effect of Adsorbent Dose on Adsorption

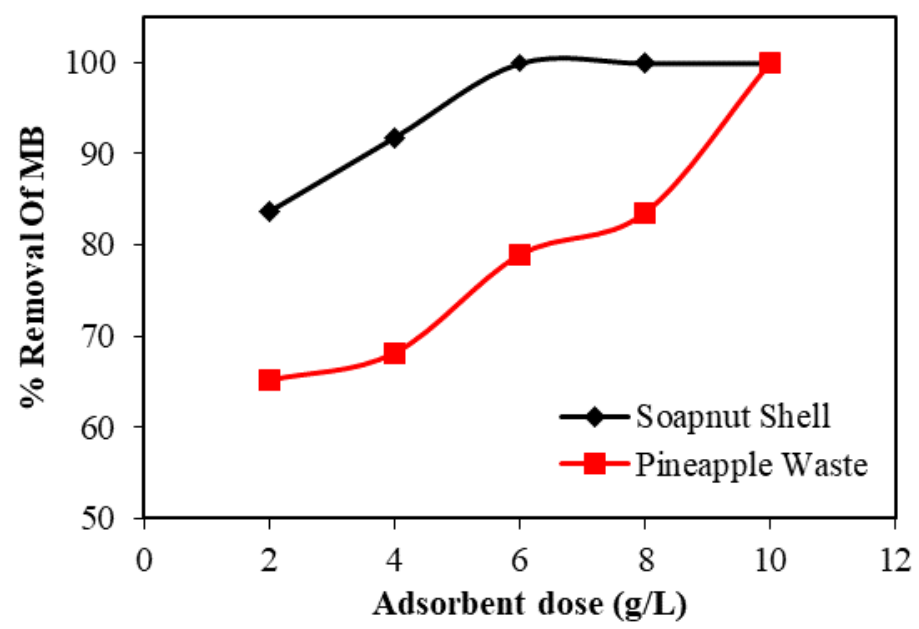

Figure 4. \% Removal of MB vs Adsorbent dose by Soapnut Shell \& Pineapple waste (Concentration of adsorbate $=100 \mathrm{ppm}$, Volume of adsorbate $=100 \mathrm{ml}$, Adsorption time $=60 \mathrm{~min}$ )

3.7 Effect of contact time on adsorption: Figure 5 shows that, at $100 \mathrm{ppm}$ concentration equilibrium contact time achieved within $120 \mathrm{~min}$ for MB after that removal efficiency become constant. Firstly, the percentage removal for MB was rapid up to 80 min thereafter it proceeds at a slower rate and finally attains saturation (Ibrahim, Haruna, \& Ibrahim, 2012; Sugumaran, Susan, Ravichandran, \& Seshadri, 2012). Generally, the contact time for adsorption is a crucial step to understand how the MB (adsorbate) approach to the adsorbent surface. The removal of the adsorbate is higher in the beginning due to the availability of high surface area after that it is saturated due to few active sites present on the adsorbent.

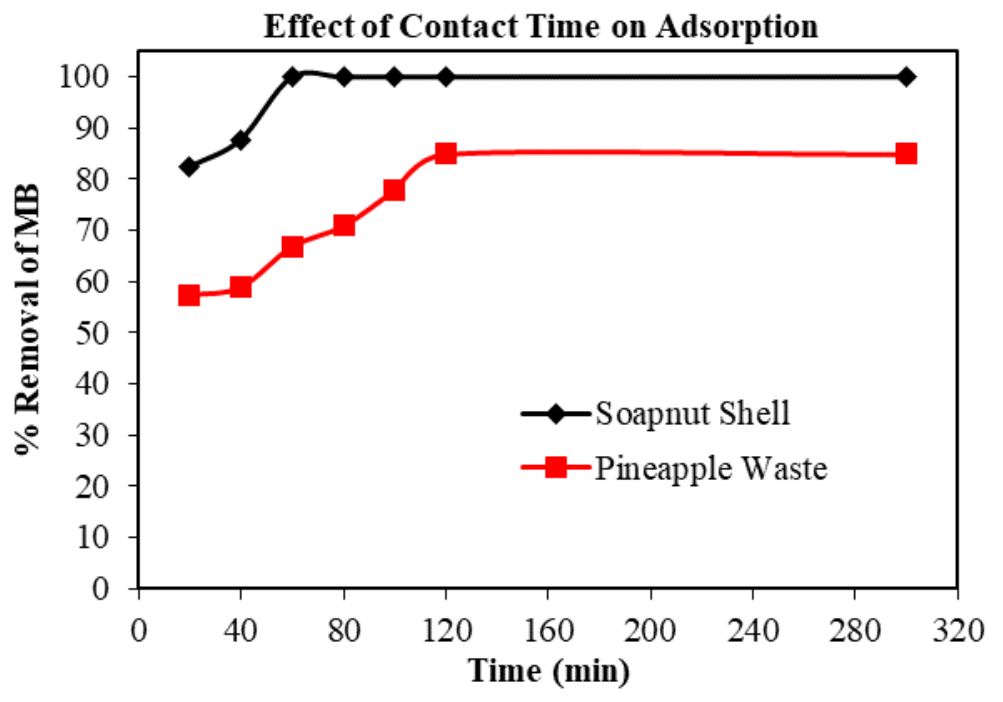

Figure 5. \% Removal of MB vs Contact time by Soapnut Shell \& Pineapple waste (Amount of adsorbent = 0.6g, Volume of adsorbate $=100 \mathrm{ml}$, Concentration of adsorbate $=100 \mathrm{ppm})$

3.8 Adsorption isotherm study: Langmuir isotherm study is carried out to understand adsorption occurring on surface of both adsorbent, Langmuir isotherm is appropriate for homogeneous (Mahamad, Zaini, \& Zakaria, 2015; Malik, 2004; Selvanathan \& Subki, 2015). In Langmuir sorption, each molecule of sorbate which is adsorb on surface of adsorbent has identical activation energy. Langmuir isotherm is represented by following Equation (3):

$$
q_{e}=\frac{K_{L} C_{e}}{1+a_{L} C_{e}}
$$

In Equation (3) $q_{e}$ represent the concentration solid phase sorbate at equilibrium condition, both $K_{\mathrm{L}}$ and $\mathrm{a}_{\mathrm{L}}$ are constants. Equation (4) is the linear form of Langmuir equation 


$$
\frac{C_{e}}{q_{e}}=\frac{1}{K_{L}}+\frac{a_{L}}{K_{L}} C_{e}
$$

In this analysis linear form of equation is used for analysis of Langmuir isotherm, value of Ce /qe vs Ce are almost linear which show reasonable fitting of Langmuir isotherm. Values of Langmuir isotherm is given in Table 3. Freundlich isotherm is used for multilayer adsorption isotherm (Hameed, Din, \& Ahmad, 2007; Joshi, Bansal, \& Purwar, 2004), represented by Equation (5):

$$
q_{e}=K_{F} C_{e}^{1 / n}
$$

where, $\mathrm{K}_{\mathrm{F}}$ is Freundlich constant. Calculated values are best fitted with Langmuir isotherm and it is shown in Table 3.

Table 3. Different properties of activated carbon

\begin{tabular}{|c|c|c|}
\hline Isotherm Parameters & Soapnut shell & Pineapple waste \\
\hline$\underline{\text { Langmuir }}$ & & \\
\hline $\mathrm{K}_{\mathrm{L}}(\mathrm{L} / \mathrm{g})$ & 9.9701 & 9.6154 \\
\hline $\mathrm{a}_{\mathrm{L}}(\mathrm{L} / \mathrm{mol})$ & 1.4138 & 1.4192 \\
\hline $\mathrm{R}^{2}$ & 0.9851 & 0.9823 \\
\hline$\underline{\text { Freundlich }}$ & & \\
\hline $\mathrm{N}$ & 7.9114 & 5.2002 \\
\hline $\mathrm{K}_{\mathrm{F}}$ & 4.52 & 3.9243 \\
\hline $\mathrm{R}^{2}$ & 0.9618 & 0.9218 \\
\hline
\end{tabular}

\section{Conclusions}

The current study present that activated carbon derived from soapnut shell and pineapple waste is an effective adsorbent for methylene blue (MB) removal from the synthetic wastewater. The adsorption efficiency depends on process parameter like run time, initial concentration, pollutants type etc. The adsorption capacity of soapnut shell is much greater than that of pineapple waste derived activated carbon. The soapnut shell possess high surface area and require lower adsorbent dose for the removal of methylene blue dye i.e. $0.6 \mathrm{~g}$, the adsorption isotherm data fits well with langmuir isotherm. The dye removal is about $99 \%$ \& $96 \%$ from soapnut shell \& pineapple waste respectively. Overall soapnut shell and pineapple waste-based adsorbent can play vital role in environmental remediation.

\section{Acknowledgement}

Authors are grateful to HBTU Kanpur for conduction of this research work.

\section{References}

Dargo, H., Gabbiye, N., \& Ayalew, A. (2015). Removal of Methylene Blue from Waste Water Using Activated Carbon Prepared from Rice Husk Removal of Methylene Blue from Waste Water Using Activated Carbon Prepared from. International Journal of Innovation and Scientific Research, 9(January), 317-325.

Gong, G., Xie, Q., Yang, W., \& Yao, X. (2013). Preparation of coal-based activated carbon and its application for methylene blue removal. Applied Mechanics and Materials, 253-255(PART 1), 988-992. https://doi.org/10.4028/www.scientific.net/AMM.253-255.988

Hameed, B. H., Din, A. T. M., \& Ahmad, A. L. (2007). Adsorption of methylene blue onto bamboo-based activated carbon: Kinetics and equilibrium studies. Journal of Hazardous Materials, 141(3), 819-825. https://doi.org/10.1016/j.jhazmat.2006.07.049

Ibrahim, M. B., Haruna, M. A., \& Ibrahim, A. M. (2012). Optimization of Crystal Violet dye removal from aqueous solution using agro wastes. ChemSearch Journal, 3(1), 28-33-33.

Joshi, M., Bansal, R., \& Purwar, R. (2004). Colour removal from textile effluents. Indian Journal of Fibre and Textile Research, 29(2), 239-259.

Kumar, P. S., Ramalingam, S., \& Sathishkumar, K. (2011). Removal of methylene blue dye from aqueous solution by activated carbon prepared from cashew nut shell as a new low-cost adsorbent. Korean Journal of Chemical Engineering, 28(1), 149155. https://doi.org/10.1007/s11814-010-0342-0

Kurniawan, A., \& Ismadji, S. (2011). Potential utilization of Jatropha curcas L. press-cake residue as new precursor for activated carbon preparation: Application in methylene blue removal from aqueous solution. Journal of the Taiwan Institute of 
Chemical Engineers, 42(5), 826-836. https://doi.org/10.1016/j.jtice.2011.03.001

Mahamad, M. N., Zaini, M. A. A., \& Zakaria, Z. A. (2015). Preparation and characterization of activated carbon from pineapple waste biomass for dye removal. International Biodeterioration and Biodegradation, 102, 274-280. https://doi.org/10.1016/j.ibiod.2015.03.009

Mahapatra, K., Ramteke, D. S., \& Paliwal, L. J. (2012). Production of activated carbon from sludge of food processing industry under controlled pyrolysis and its application for methylene blue removal. Journal of Analytical and Applied Pyrolysis, 95, 79-86. https://doi.org/10.1016/j.jaap.2012.01.009

Malik, P. K. (2004). Dye removal from wastewater using activated carbon developed from sawdust: Adsorption equilibrium and kinetics. Journal of Hazardous Materials, 113(1-3), 81-88. https://doi.org/10.1016/j.jhazmat.2004.05.022

Mohammed MA, Shitu A, \& Ibrahim A. (2014). Removal of Methylene Blue Using Low Cost Adsorbent: A Review. Research Journal of Chemical Sciences, 4(1), 91-102. Retrieved from www.isca.me

Öden, M. K., \& R, C. Ö. (2014). Removal of Methylene Blue Dye From Aqueous Solution Using Natural Boron Ore And Leach Waste Material : Adsorption Optimization Criteria. International Journal of Current Research and Academic Review, 1(1), 66-71.

Ozer, C., Imamoglu, M., Turhan, Y., \& Boysan, F. (2012). Removal of methylene blue from aqueous solutions using phosphoric acid activated carbon produced from hazelnut husks. Toxicological and Environmental Chemistry, 94(7), 1283-1293. https://doi.org/10.1080/02772248.2012.707656

Patel, H., \& Vashi, R. T. (2012). Removal of Congo Red dye from its aqueous solution using natural coagulants. Journal of Saudi Chemical Society, 16(2), 131-136. https://doi.org/10.1016/j.jscs.2010.12.003

Pathania, D., Sharma, S., \& Singh, P. (2017). Removal of methylene blue by adsorption onto activated carbon developed from Ficus carica bast. Arabian Journal of Chemistry, 10, S1445-S1451. https://doi.org/10.1016/j.arabjc.2013.04.021

Patil, S., Renukdas, S., \& Patel, N. (2011). Removal of methylene blue, a basic dye from aqueous solutions by adsorption using teak tree ( Tectona grandis) bark powder. Removal of Methylene Blue, a Basic Dye from Aqueous Solutions by Adsorption Using Teak Tree ( Tectona Grandis) Bark Powder, 1(5), 711-726.

Selvanathan, N., \& Subki, N. S. (2015). Dye adsorbent by pineapple activated carbon: $\mathrm{H}_{3} \mathrm{PO}_{4}$ and $\mathrm{NaOH}$ activation. ARPN Journal of Engineering and Applied Sciences, 10(20), 9476-9480.

Singh, K. P., Mohan, D., Sinha, S., Tondon, G. S., \& Gosh, D. (2003). Color removal from wastewater using low-cost activated carbon derived from agricultural waste material. Industrial and Engineering Chemistry Research, 42(9), 1965-1976. https://doi.org/10.1021/ie020800d

Sugumaran, P., Susan, V. P., Ravichandran, P., \& Seshadri, S. (2012). Production and Characterization of Activated Carbon from Banana Empty Fruit Bunch and Delonix regia Fruit Pod. Journal of Sustainable Energy \& Environment, 3, 125-132.

Sunanda, Tiwari, D. P., Sharma, D. N., \& Raunija, T. S. K. (2013). Sapindus Based Activated Carbon by Chemical Activation. Rsearch Journal of Material Sciences, 1(7), 9-15. Retrieved from http://www.isca.in/MATERIAL_SCI/Archive/v1/i7/2.ISCA-RJMatS-2013-025.pdf

Yang, J., \& Qiu, K. (2010). Preparation of activated carbons from walnut shells via vacuum chemical activation and their application for methylene blue removal. Chemical Engineering Journal, 165(1), 209-217. https://doi.org/10.1016/j.cej.2010.09.019

\section{Biographical notes}

Ratnesh Kumar Patel received M. Tech. from Harcourt Butler Technical University Kanpur, India in 2016. Presently he is a Research Scholar in the Department of Chemical Engineering, Madan Mohan Malaviya University of Technology Gorakhpur, India.

Dr. Ram Prasad is a Professor in the Department of Chemical Engineering, Harcourt Butler Technical University Kanpur, India. He has more than 30 years of experience in teaching and research. He is author of many chemical engineering books and published more than 100 papers in national and international journals.

Dr. Ravi Shankar is a Assistant Professor in the Department of Chemical Engineering, Madan Mohan Malaviya University of Technology Gorakhpur, India. He has 4 years of experience in teaching and research. He has published more than 20 papers in international and national journals.

Dr. Prateek Khare is a Assistant Professor in the Department of Chemical Engineering, Madan Mohan Malaviya University of Technology Gorakhpur, India. He has more than 2 years of experience in teaching and research. He has published more than 20 papers in international and national journals.

Maharshi Yadav received M. Tech. in Environmental Engineering from Madan Mohan Malaviya University of Technology Gorakhpur, India and presently he is a Research Scholar in the Department of Chemical Engineering, Madan Mohan Malaviya University of Technology Gorakhpur, India. 